\title{
O TRABALHO INFANTIL NO BRASIL CONTEMPORÂNEO
}

\author{
Inaiá Maria Moreira de Carvalho*
}

\begin{abstract}
Este trabalho analisa o panorama atual do trabalho infantil na sociedade brasileira, abordando a sua origem, trajetória recente, efeitos sobre as crianças e adolescentes e políticas que vêm sendo desenvolvidas para combatê-lo. Baseando-se em tabulações especiais da PNAD de 2006, ele mostra a dimensão do fenômeno e como a atividade precoce se diferencia conforme a idade, o sexo, a residência rural e urbana e as grandes regiões, assinalando suas condições de atividade e seus impactos perversos sobre a educação e a saúde dos pequenos trabalhadores. Considerando tanto os determinantes econômicos como os valores e representações simbólicas que estão na base da sua reprodução, o texto conclui destacando como, nas condições do desenvolvimento brasileiro, esse é um fenômeno de difícil erradicação.

PALAVRAS CHAVE: trabalho infantil, crianças e adolescentes, desigualdade social, Brasil.
\end{abstract}

\section{INTRODUÇÃO}

Tão perversas quanto persistentes, as desigualdades sociais e a pobreza atingem particularmente alguns contingentes da população brasileira, como as crianças e adolescentes. De acordo com o último Censo, $45 \%$ dos seus integrantes pertenciam a famílias com renda per capita até meio salário mínimo no ano 2000, e esse percentual era ainda mais elevado nas regiões Norte e Nordeste e em estados como o Maranhão, Piauí, Alagoas, Pernambuco e Bahia. Em 2006, conforme informações da PNAD, 46,5\% do contingente de 5 a 17 anos permaneciam nessa condição, o que contribui para que milhares de crianças e adolescentes sejam expostos a diversas situações de risco, vio-

\footnotetext{
* Doutora em Sociologia. Professora do Mestrado em Políticas Sociais e Cidadania da Universidade Católica de Salvador e do Programa de Pós-Graduação em Ciências Sociais da Universidade Federal da Bahia. Pesquisadora do Centro de Recursos Humanos da Universidade Federal da Bahia. Bolsista do CNPq-IB.

Avenida Anita Garibaldi, 2981. Cep: 41.940-210. Rio Vermelho - Salvador - Bahia - Brasil. inaiammc@ufba.br

A autora agradece a Cláudia Monteiro Fernandes, que efetuou as tabulações especiais da PNAD 2006 e fez pertinentes comentários a este texto, com a generosidade e
} competência habituais. lência e exploração, entre outros aspectos, pela inserção precoce no mundo do trabalho.

Enfrentando a imperiosa necessidade de contribuir para o orçamento doméstico ou, algumas vezes, de assegurar a própria subsistência, meninos e meninas são obrigados a reprimir energias, sentimentos e comportamentos que caracterizam a infância e a adolescência nas sociedades modernas (Àries, 1978) e que ainda constituem privilégio das camadas altas e médias no Brasil. Fragilizados e indefesos, transfiguram-se prematuramente em adultos e, como trabalhadores infanto-juvenis, enfrentam condições marcadas pela precariedade ocupacional, jornadas prolongadas, ganhos reduzidos ou inexistentes e a negação do direito a uma formação educacional e profissional que possa lhes propiciar melhores oportunidades de inserção futura.

Considerando a relevância desse fenômeno, o presente texto analisa o panorama atual do trabalho infanto-juvenil na sociedade brasileira, discutindo a sua origem e trajetória recente, os efeitos da ocupação precoce sobre as crianças e adolescentes, as políticas que vêm sendo desenvolvidas para combatê-la e as perspectivas da sua erradicação. 


\section{O TRABALHO PRECOCE NO BRASIL}

Dando início a essas análises, vale lembrar que o Brasil tem uma longa história de exploração da mão-de-obra infantil. Como assinala Rizzini (2007), para os donos das crianças escravas na Colônia e no Império, para os capitalistas no início da industrialização, para os grandes proprietários de terra, nas unidades domésticas de produção artesanal ou agrícola, nas casas de família e nas ruas, as crianças pobres sempre trabalharam no país.

Documentos da época fazem referências à ocupação das crianças escravas desde cedo; dos quatro aos onze anos, todo o seu tempo ia sendo paulatinamente ocupado pelo trabalho (Góes; Florentino, 2007); crianças pobres e órfãs também eram recrutadas para o trabalho nas fazendas e nas casas dos "senhores", onde eram exploradas e até abusadas (Grunspun, 2000). E como a experiência da escravidão mostrou que essa era uma mão-deobra dócil, mais barata e adaptável ao trabalho, após a abolição e o advento da República, multiplicaram-se as iniciativas públicas e privadas para formar, disciplinar e incorporar seus pequenos braços à agricultura e à indústria, atividades nas quais chegavam a trabalhar 12 horas por dia, sob rígida disciplina e em ambientes insalubres, onde adquiriam doenças como a tuberculose. ${ }^{1}$

Além disso, a questão da infância pobre tor-

nou-se objeto de preocupações e discussões desde o final do século XIX no Brasil, com o advento da República, o crescimento de algumas metrópoles, a criação de uma força de trabalho urbana e, posteriormente, o início de um processo de industrialização (Alvim; Valladares, 1981). Mas, como a visão desse problema partia de um conjunto de preconceitos e representações negativas sobre as classes populares, ${ }^{2}$ essas crianças eram vistas como vítimas do abandono ou do comportamento de famílias

${ }^{1}$ Conforme Rizzini (2007), relatório médico de 1914 apontou a existência de $70 \%$ de tuberculosos entre os adolescentes aprendizes de duas oficinas do Rio de Janeiro. Em 1894, do operariado de quatro estabelecimentos têxteis inspecionados em São Paulo, 25\% eram menores; levantamento realizado em 1919, em cento e noventa e quatro estabelecimentos industriais aí localizados, constatou igualmente que $25 \%$ da mão-de-obra operária tinham menos de 18 anos. desorganizadas e incapazes de socializá-las dentro dos valores da moral e dos bons costumes, assim como da exploração de adultos inescrupulosos. Esses as jogavam nas ruas, em contato com um mundo cheio de mazelas e vícios, propícios à formação de indivíduos vadios, indisciplinados e incapazes para o trabalho, cuja reprodução social se daria pela mendicância e pelo crime.

Concepções dessa ordem orientaram uma série de políticas e medidas destinadas a proteger a mão-de-obra infanto-juvenil nas fábricas (largamente utilizada no início da industrialização), assim como a combater o mal estar social provocado pela mendicância e pela criminalidade urbana. Com um caráter assistencialista e correcional repressivo, elas estavam centradas na criação de instituições especializadas na "proteção" ou "recuperação" dos denominados "menores", ${ }^{3}$ privilegiando o seu internamento em instituições totais e a sua inserção no mundo do trabalho, para transformálos em "indivíduos úteis à sociedade" e em futuros bons cidadãos.

É verdade que, a partir de 1927, quando o Código de Menores foi publicado, algumas leis e disposições constitucionais procuraram regular a utilização dessa mão-de-obra, proibindo-a abaixo de certos limites de idade, ${ }^{4}$ em horários noturnos, locais perigosos e insalubres, ou em atividade no-

Na medida em que a sociedade brasileira não foi capaz de universalizar o assalariamento, boa parte da população teve de buscar sua subsistência através de formas de ocupação não cobertas pela legislação, à margem das regras que regulamentavam o mercado. Essa condição estrutural de inserção econômica e social imprimiu sobre esse grupo a visão preconceituosa e segregacionista de "vadios" e delinqüentes em potencial, que se estendeu às crianças e jovens das classes populares.

${ }^{3}$ Utilizado de uma forma ampla até recentemente para denominar a infância e a juventude das classes populares, esse conceito é diferente daqueles utilizados para designar os não adultos de outras classes sociais (que são chamados de meninos, crianças, garotos, jovens ou adolescentes), como ressaltam Alvim e Valladares (1981). Esse conceito tem uma base jurídica, reportando-se a uma pessoa cuja idade a coloca em uma situação distinta perante a lei, e embutindo, no seu significado, as noções de pobreza e de delinqüência.

${ }^{4}$ A Constituição brasileira de 1934, por exemplo, proibia o trabalho dos menores de 14 anos, salvo com permissão judicial. A Constituição de 1967 reduziu essa idade para 12 anos. Na de 1988 e no Estatuto da Crianca e do Adolescente esse limite voltou aos 14 anos. Sobre a evolução da legislação sobre o trabalho infanto-juvenil e as justificativas ideológicas apresentadas por setores interessados na sua utilização, ver Alvim (1994). 
civas ao desenvolvimento físico e moral dos seus executores (Grunspun, 2000). Mas essas leis eram comumente questionadas e burladas e, além disso, sua proteção praticamente não se estendeu ao meio rural, onde até hoje uma grande parcela de mão-de-obra infanto-juvenil permanece ocupada em diversos setores, principalmente como parte integrante da força de trabalho familiar. Mesmo incorporando crianças de pouca idade e em condições penosas, esse trabalho não despertou um maior interesse por parte dos médicos, juristas e higienistas (como ocorreu nas áreas urbanas), continuando a ser visto como natural ou até saudável, principalmente porque, na maioria dos casos, ele se desenvolve entre os membros da unidade familiar (Dourado; Dabat; Araújo, 2007).

Essas concepções só começaram a ser contestadas e transformadas quando se constituiu um amplo movimento em favor das crianças e adolescentes brasileiros (notadamente daqueles marginalizados), no período da redemocratização. Como se sabe, partindo de uma crítica ao velho e falido modelo assistencialista e correcional repressivo, que embasava, tradicionalmente, as políticas e medidas orientadas para o segmento em discussão, esse movimento definiu as crianças e adolescentes como sujeitos de amplos direitos, que deveriam ser respeitados pela sua condição especial de pessoas em desenvolvimento; procurou assegurar esses direitos e uma proteção integral que os protegesse de todas as formas de negligência, violência, exploração e opressão, através do artigo 227 da Constituição de 1988 e do Estatuto da Criança e do Adolescente, promulgado em 1990, e passou a realizar um amplo movimento de sensibilização da opinião pública e de pressão política para que essas novas orientações fossem realmente efetivadas (Fausto; Cervini, 1991; Carvalho, 1995).

Entendendo que a infância e a adolescência devem representar um período lúdico, preservado de maiores responsabilidades e voltado para o desenvolvimento e a preparação para a idade adulta, o Estatuto proibiu qualquer trabalho a menores de 14 anos e procurou assegurar o direito à profissionalização e proteger a ocupação de apren- dizes e demais adolescentes. Para isso, definiu a condição de aprendiz como uma situação de formação técnico-profissional conduzida de acordo com as diretrizes e bases da legislação educacional em vigor e exigiu que essa ocupação seja sempre compatível com a freqüência escolar e lhes ofereça certas garantias, vedando o seu exercício em horários noturnos, condições insalubres e penosas ou locais que prejudiquem o desenvolvimento físico, psíquico, moral e social dos seus executores.

Essas determinações encontraram resistências que podem ser ilustradas por um editorial publicado em 1993 pelo jornal de maior circulação e prestígio do estado da Bahia, referindo-se aos esforços do Ministério do Trabalho para erradicar o trabalho infantil no país.

Pura demagogia esta do ministro Walter Barelli, do Trabalho, de verberar contra o trabalho de crianças entre 12 e 14 anos, na lavoura e em outras atividades [...].

Crianças e jovens que poderiam, não fosse uma atividade remunerada, estar nas ruas e engrossar o contingente de abandonados, de carentes, num convívio quase compulsório com a marginalidade.

O trabalho de crianças e jovens a partir dos 12 anos ou dos 14 anos deveria ser estimulado pelo Ministério do Trabalho e não criticado [...]. Não está no trabalho o caminho do crime. Está no ócio, que o ministro Barelli estranhamente defende para a criança e para a juventude. É incrível! (A Tarde, 15 jun. 1993, p.6, conforme Carvalho, 1995, p.130).

Nessa ocasião, o próprio Juiz de Menores de Salvador defendia o trabalho dos jovens em condições contrárias às determinações do Estatuto, que ele considerava "irrealista" e "inaplicável", considerando que

A lei é norte, é indicador. Mas toda vez que há um interesse social relevante, a lei deve ser contornada. (Carvalho, 1995, p.127)

\section{AS TRANSFORMAÇÕES DOS ANOS 1990}

Com o tempo e ainda que lentamente, porém, os valores e disposições do Estatuto começaram a ser socialmente assimilados e cobrados, e os antigos "menores" percebidos como apenas crian- 
ças cujo lugar é na escola, não na produção, desnaturalizando-se e deslegitimando-se o seu trabalho. Além disso, nesse contexto de mudanças, em 1992, o Brasil passou a fazer parte do Programa Internacional para a Erradicação do Trabalho Infantil - IPEC, da Organização Internacional do Trabalho. Em 1994 foi criado e instalado o Fórum Nacional de Prevenção e Erradicação do Trabalho Infantil, sob a coordenação do Ministério do Trabalho, com o apoio do Unicef e a participação de organizações não-governamentais, empresários, representantes de Sindicatos, da Igreja, do Poder Legislativo e do Judiciário. No segundo semestre de 1996, o Fórum Nacional lançou um Programa de Ações Integradas, que traçou o caminho para a implementação do Programa de Erradicação e Prevenção do Trabalho Infantil-PETI no país, orientado para o combate às chamadas "piores formas" desse trabalho, ou seja, àquelas consideradas perigosas, penosas, insalubres ou degradantes.

Com o apoio da OIT e do Unicef, o Programa começou a operar no Mato Grosso do Sul, onde duas mil e quinhentas crianças trabalhavam na produção de carvão vegetal e viviam em condições inaceitáveis. Pouco depois, ele se estendeu aos Estados de Pernambuco e Bahia, contemplando a zona canavieira e a região do sisal. Priorizando o atendimento às famílias com renda per capita de até meio salário mínimo, ou seja, aquelas que viviam em situação de extrema pobreza, o PETI passou a oferecer a essas famílias uma compensação financeira para a retirada das crianças do trabalho, condicionada à sua freqüência regular à escola, assim como à “Jornada Ampliada” no turno complementar. Além do almoço e da merenda reforçados, a Jornada deveria propiciar reforço escolar, atividades culturais, esportivas e de lazer às crianças atendidas, contribuindo para a melhoria do seu desempenho escolar, a ampliação dos seus horizontes e o desenvolvimento de suas potencialidades.

Em 2000, o Programa sofreu algumas redefinições e experimentou uma significativa expansão, passando de cerca de 140.000 para 810.769 beneficiários em 2002, estendendo-se às áreas urbanas e metropolitanas e contemplando um maior elen- co de atividades que utilizam o trabalho precoce em condições especialmente adversas, como os lixões, o comércio ambulante, os cultivos de algodão, fumo, café e laranja, e a ocupação em cerâmicas, olarias, garimpos e pedreiras, entre outras.

Apesar das dificuldades e limitações, apontadas em estudos como os de Souza e Souza (2003) e Carvalho (2004), não se podem desconhecer a relevância e as contribuições do PETI. Ele propiciou a retirada imediata de milhares de crianças e adolescentes de ocupações penosas e degradantes, sua permanência na escola e uma melhoria nas suas condições de subsistência (ainda que reduzida e temporária), resgatando sua dignidade e sua infância, como bem ilustra o depoimento de uma mãe cujos filhos, beneficiários do PETI, trabalhavam antes em um lixão.

Hoje (os filhos) não perdem mais aula, só se preocupam em estudar. Hoje eles andam como seres humanos, se vestem direitinho, cuidam da saúde. Antes não tinha banho que tirasse o mau cheiro; não andam com pé cortado, ferimentos, com crecas (sic). Andam com a pele limpinha. Tinha muita discriminação com meus filhos, porque andavam no lixo, hoje não tem mais isso, (os outros) diziam que comia lixo, chamavam eles de fedorentos. (Souza; Souza, 2003).

As mudanças e iniciativas assinaladas contribuíram para uma redução expressiva do trabalho precoce no Brasil. Conforme série histórica produzida pelo IBGE (divulgada pela Folha de São Paulo de 29 mar. 2008), em 1992, o percentual de meninos e meninas entre 5 e 17 anos que trabalhavam chegava a 19,6\% no Brasil. Esse número decresceu para 18,7\% em 1999, 15,1\% em 1995 e $12,6 \%$ em 2002, devendo ser ressaltado que foi entre 1999 e 2002 que o PETI teve a sua maior expansão de metas. O núcleo duro dessa ocupação continuou a ser a pequena produção familiar rural ou urbana, uma vez que $47,73 \%$ das crianças e adolescentes ocupados trabalhava como não remunerados, $22,36 \%$ como empregados, $6,44 \%$ como trabalhadores domiciliares, 6,31\% por "conta própria”, 9,4\% na produção para o autoconsumo, 7,35\% como empregados domésticos, 0,37\% na autoconstrução e 0,01\% como empregadores. (Ministério do Trabalho e Emprego, 2005, p. 15). 
Mas, como as raízes do problema permaneceram praticamente intocadas, depois desse período a queda em apreço tornou-se mais lenta e nem sempre continuada, com os pequenos trabalhadores alcançando $11,7 \%$ da população entre 5 e 17 anos em 2003, 11,4\% em 2004 e 11,8\% em 2005. Tal fato justifica uma declaração recente da Secretária Executiva do Fórum Nacional de Prevenção e Erradicação do Trabalho Infantil de que "O cenário do Brasil no combate ao trabalho infantil é de estagnação" (Folha de São Paulo, 29 mar. 2008). ${ }^{5}$

\section{O PANORAMAATUAL}

Os dados mais recentes, disponíveis, coletados pela PNAD de 2006, deixam patente que, apesar da proibição legal, 1,4 milhões de crianças de 5 a 13 anos estavam ocupadas na semana da pesquisa, 571 mil delas nos centros urbanos e 835 mil nas áreas rurais. Dos 5 aos 17 anos, esses números atingiam 5,1 milhões, sendo 3 milhões residentes nas áreas urbanas e 2 milhões nas áreas rurais, o que representava, respectivamente, $11,5 \%$, $8,4 \%$ e $23,9 \%$ dos que residiam no país e nas referidas áreas.

A ocupação precoce persistia relativamente mais elevada no Nordeste e no Sul do país (onde o contingente em apreço atingia 12,5\% e 13,6\%, contra $12,4 \%$ no Norte, $8,4 \%$ no Sudeste e 9,9\% no Centro-Oeste), assim como em estados onde a agropecuária tem um maior peso econômico, como Maranhão, Piauí, Ceará, Paraíba, Pernambuco, Alagoas, Bahia, Minas Gerais, Paraná, Santa Catarina e Rio Grande do Sul. Em números absolutos, porém, destacavam-se o Nordeste (onde a população entre 5 e 17 anos, que vivia em famílias com renda per capita inferior a meio salário mínimo, chegava a $61,2 \%$ nas áreas urbanas, $85,9 \%$ nas áreas rurais e $69,1 \%$ no conjunto da região) e

${ }^{5}$ Além disso, a partir de 2005, a PNAD constatou certo crescimento da mão-de-obra infantil em setores informais da economia e, no primeiro semestre de 2007, mais que dobrou o número de crianças encontradas pela fiscalização do Ministério do Trabalho que exerciam atividades laborais ilegalmente em empresas e pequenos negócios (Folha de São Paulo, 26 jul, 2007). o Sudeste, conforme os dados da Tabela 1.

Tanto a Tabela como os Gráficos que a seguem deixam patente que, embora as crianças pequenas tendam a ser poupada, sua atividade laboral pode começar antes dos 10 anos, principalmente nas áreas rurais do Norte, Nordeste e Sul do Brasil. A partir dessa idade, ela se amplia, chegando a $25,4 \%$ na faixa dos 10 a 13 anos nas áreas rurais do Nordeste, $28,4 \%$ do Norte e 30,0\% do Sul. Continuando a avançar com o tempo, torna-se ainda bem mais significativa a partir dos 14 anos, quando já se encontravam ocupados $22,1 \%$ dos que residiam nas cidades, $46,9 \%$ no campo e $26,9 \%$ no país como um todo, com diferenças regionais apresentadas a seguir.

Os Gráficos também evidenciam como a ocupação dos meninos normalmente é superior à das meninas (ainda que, em termos percentuais, as diferenças não sejam tão marcantes), ${ }^{6}$ o que é consistente com a divisão sexual do trabalho, com a maior dedicação das mulheres aos afazeres domésticos e com os valores relativos a questões de gênero que prevalecem na sociedade brasileira. Entre os $16 \mathrm{e} 17$ anos, porém, a ocupação feminina passa de $103 \mathrm{mil}$ para 636 mil adolescentes no meio rural e de 411 mil para 1,2 milhões no meio urbano, chegando a representar 34,4\% do contingente de mulheres com 17 anos que residem nas cidades, contra 31,3\% verificados entre os jovens do sexo masculino. ${ }^{7}$

As evidências apresentadas já começam a deixar claro que, como seria de se esperar, a inser-

${ }^{6}$ Como se sabe, pequenas diferenças percentuais podem estar associadas a números bem maiores em termos absolutos. Para o conjunto do Brasil, por exemplo, na faixa dos 16 anos, havia 827.972 meninos e 512.027 meninas ocupadas, o que correspondia respectivamente a $21,1 \%$ e $20,8 \%$ de cada um desses grupos.

${ }^{7}$ Chamando a atenção para os determinantes não econômicos de ocupação precoce, um texto mais antigo de Alvim (1994) já assinalava que, cabendo ao pai, como chefe de família, a responsabilidade maior pela sua manutenção, a incorporação produtiva dos demais componentes ocorria não apenas em função das necessidades econômicas do grupo, mas também de uma hierarquia que considerava os jovens do sexo masculino de 14 anos ou mais como os que deveriam trabalhar prioritariamente; seguindo-se as filhas adolescentes e as mães. Só quando a renda mais baixa exigia é que as crianças deveriam ser incorporadas.

$\mathrm{Na}$ faixa dos 17 anos, é possível que os meninos sejam mais atingidos pelo desemprego nos centros urbanos, enquanto as meninas encontram oportunidades nos serviços domésticos e em ocupações similares. 
Tabela 1 - População ocupada entre os 5 e 17 anos - Brasil e Grandes Regióes - 2006

\begin{tabular}{|c|c|c|c|c|c|c|c|c|}
\hline \multirow{3}{*}{$\begin{array}{c}\text { Brasil e } \\
\text { Grandes } \\
\text { Regiōes }\end{array}$} & \multicolumn{8}{|c|}{ Crianças de 5 a 17 anos } \\
\hline & \multicolumn{2}{|c|}{ Total } & \multicolumn{2}{|c|}{5 a 9 anos } & \multicolumn{2}{|c|}{10 a 13 anos } & \multicolumn{2}{|c|}{14 a 17 anos } \\
\hline & $\mathrm{N}$ & $\%$ & $\mathrm{~N}$ & $\%$ & $\mathrm{~N}$ & $\%$ & $\mathrm{~N}$ & $\%$ \\
\hline Brasil & 5.137 .209 & 11,5 & 237.280 & 1,4 & 1.168 .330 & 8,2 & 3.731 .549 & 26,9 \\
\hline Norte & 539.231 & 12,4 & 30.421 & 1,8 & 157.027 & 11,4 & 351.783 & 27,4 \\
\hline Nordeste & 1.985 .047 & 14,4 & 130.283 & 2,5 & 561.834 & 12,9 & 1.292 .930 & 30,3 \\
\hline Sudeste & 1.452 .070 & 8,4 & 28.787 & 0,4 & 214.775 & 4,0 & 1.208 .508 & 22,3 \\
\hline Sul & 839.541 & 13,6 & 38.654 & 1,7 & 182.126 & 9,0 & 618.761 & 32,7 \\
\hline Centro Oeste & 321.320 & 9,9 & 9.135 & 0,8 & 52.618 & 5,0 & 259.567 & 25,8 \\
\hline Urbano & 3.037 .079 & 8,4 & 81.035 & $\mathbf{0 , 6}$ & 489.708 & 4,3 & 2.466 .318 & 22,1 \\
\hline Norte & 243.206 & 7,6 & 9.264 & 0,7 & 46.645 & 4,7 & 187.297 & 19,8 \\
\hline Nordeste & 889.813 & 9,5 & 39.386 & 1,1 & 205.598 & 6,9 & 644.829 & 22,4 \\
\hline Sudeste & 1.170 .125 & 7,5 & 15.187 & 0,3 & 140.348 & 2,8 & 1.014 .590 & 20,6 \\
\hline Sul & 500.622 & 9,9 & 15.243 & 0,8 & 68.424 & 4,2 & 416.955 & 26,9 \\
\hline Centro Oeste & 233.313 & 8,4 & 1.973 & 0,2 & 28.693 & 3,2 & 202.647 & 23,1 \\
\hline Rural & 2.100 .130 & 23,9 & 156.227 & 4,8 & 678.672 & 24,0 & 1.265 .231 & 46,9 \\
\hline Norte & 296.025 & 25,2 & 21.157 & 4,7 & 110.382 & 28,4 & 164.486 & 48,4 \\
\hline Nordeste & 1.095 .234 & 24,6 & 90.897 & 5,5 & 356.236 & 25,4 & 648.101 & 46,7 \\
\hline Sudeste & 281.945 & 17,7 & 13.600 & 2,3 & 74.427 & 14,8 & 193.918 & 38,5 \\
\hline Sul & 338.919 & 30,3 & 23.411 & 5,8 & 113.702 & 30,0 & 201.806 & 59,1 \\
\hline Centro Oeste & 88.007 & 18,8 & 7.162 & 3,9 & 23.925 & 15,3 & 56.920 & 44,6 \\
\hline
\end{tabular}

Fonte: IBGE/PNAD, 2006. Dados tabulados para este trabalho.

Gráfico 1 - Pirâmide etária das crianças de 5 a 17 anos, por idade pontual Total de residentes e ocupados (\%)

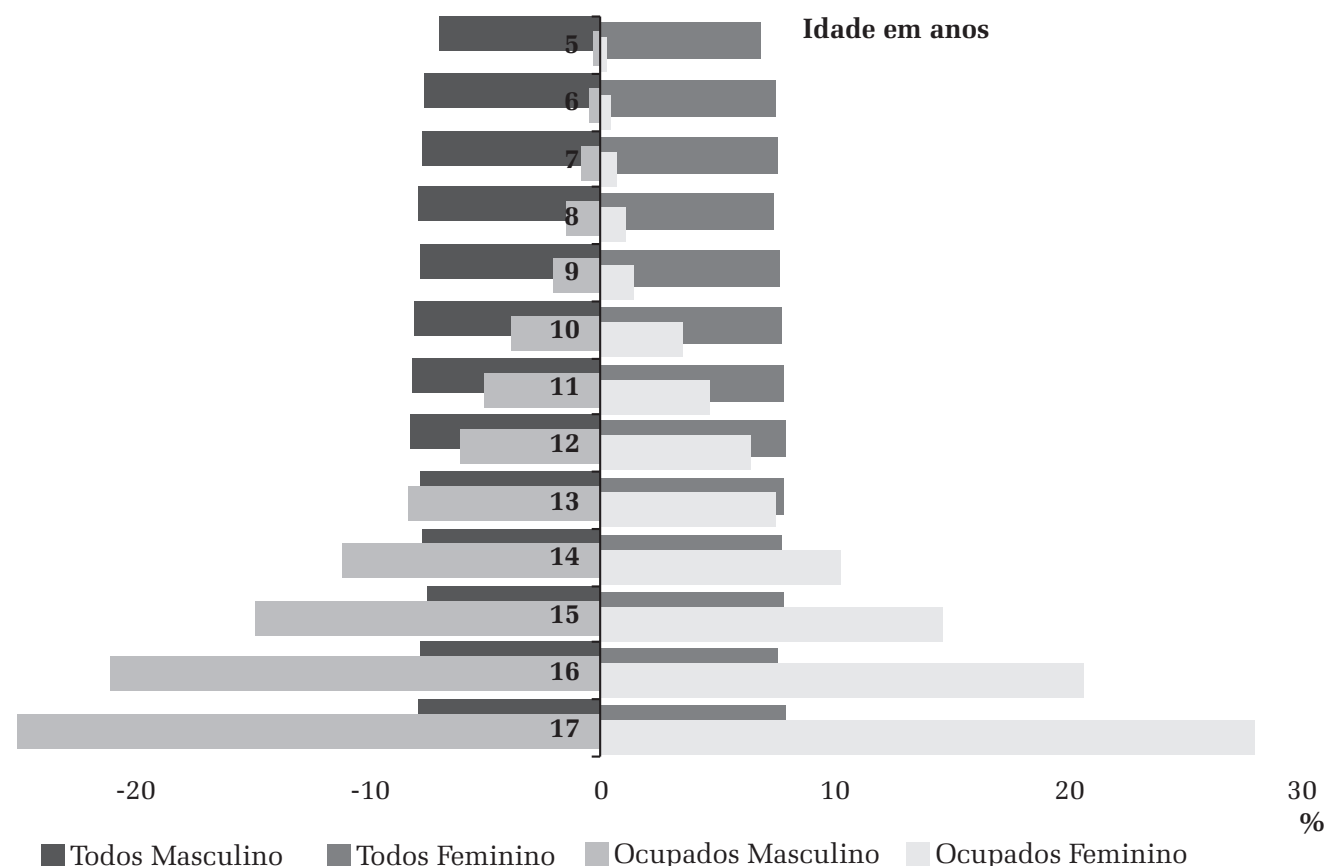


Gráfico 2 - Pirâmide etária das crianças de 5 a 17 anos, por idade pontual Ocupados em áreas urbanas e rurais (\%)

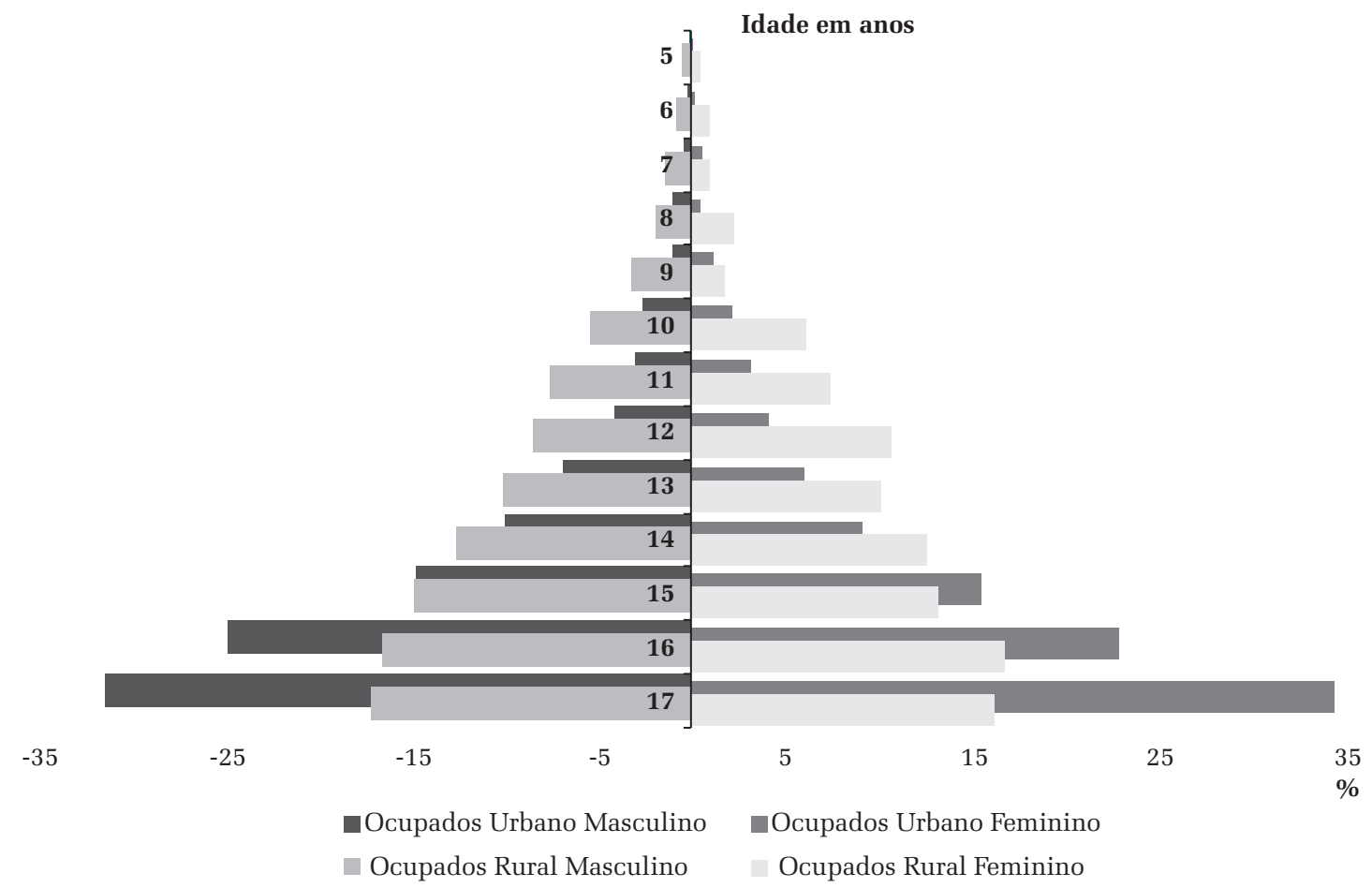

ção ocupacional precoce obedece a padrões que se diferenciam conforme a faixa de idade, o sexo, a residência rural ou urbana e as regiões. Até os 9 anos, as crianças estão ocupadas fundamentalmente em atividades agrícolas, como auxiliares não remunerados de membros da unidade domiciliar ou trabalhadores para o próprio consumo, notadamente no Nordeste e no Sul do Brasil, onde a produção agropecuária e as pequenas proprieda- des de caráter familiar têm uma maior expressão. Na faixa de 10 a13 anos, a vinculação a atividades não agrícolas já se torna predominante, pois há uma grande queda dos ocupados na produção para o próprio consumo e um crescimento do número de empregados (categoria de maior freqüência na região Sudeste), de trabalhadores domésticos e por "conta própria"; mas a condição de auxiliar de membro da unidade domiciliar persiste ainda como

Tabela 2 - População ocupada entre 5 e 17 anos, segundo as atividades agrícolas e não agrícolas (em percentuais)

\begin{tabular}{|c|c|c|c|c|c|c|c|c|}
\hline \multirow{2}{*}{$\begin{array}{c}\text { Brasil e } \\
\text { Grandes } \\
\text { Regiōes }\end{array}$} & \multicolumn{2}{|c|}{ Total } & \multicolumn{2}{|c|}{5 a 9 Anos } & \multicolumn{2}{|c|}{10 a 13 Anos } & \multicolumn{2}{|c|}{14 a 17 Anos } \\
\hline & Agrícola & $\begin{array}{c}\text { Não } \\
\text { Agrícola }\end{array}$ & Agrícola & $\begin{array}{c}\text { Não } \\
\text { Agrícola }\end{array}$ & Agrícola & $\begin{array}{c}\text { Não } \\
\text { Agrícola }\end{array}$ & Agrícola & $\begin{array}{c}\text { Não } \\
\text { Agrícola }\end{array}$ \\
\hline Brasil & 41,4 & 58,6 & 75,6 & 24,4 & $\mathbf{5 9 , 9}$ & 40,1 & 33,4 & 66,6 \\
\hline Norte & 45,1 & 54,9 & 72,4 & 27,6 & 57,1 & 42,9 & 37,4 & 62,6 \\
\hline Nordeste & 57,5 & 42,5 & 77,8 & 22,2 & 66,9 & 33,1 & 51,3 & 48,7 \\
\hline Sudeste & 21,1 & 78,9 & 62,1 & 37,9 & 41,2 & 58,8 & 16,6 & 83,4 \\
\hline Sul & 41,6 & 58,4 & 79,5 & 20,5 & 66,9 & 33,1 & 31,8 & 68,2 \\
\hline Centro oeste & 26,6 & 73,4 & 82,2 & 17,8 & 47,2 & 52,8 & 20,4 & 79,6 \\
\hline
\end{tabular}

Fonte: IBGE/PNAD, 2006. Dados tabulados para este trabalho. 
a mais numerosa, principalmente no Norte, no Nordeste e na região Sul.

Entre 14 e 17 anos, quando cerca de um quarto dos adolescentes já se encontrava em atividade e outros à procura de trabalho, a mudança no padrão de ocupação é bem mais radical. Com exceção do Nordeste, as atividades não agrícolas tornam-se amplamente majoritárias, chegando a $79,6 \%$ no Centro-Oeste e $83,4 \%$ no Sudeste. O trabalho não remunerado, como auxiliar de membro da unidade domiciliar, cai ainda mais significativamente (não representando mais que 13,7\% dos ocupados nessa faixa etária no país e $8,8 \%$ no Sudeste, embora seu peso continue mais relevante no Norte e no Nordeste), enquanto a condição de empregado se eleva para $41,2 \%$ na região Norte, $43,7 \%$ no Nordeste, $71,4 \%$ no Sudeste, $70,9 \%$ no Sul e 65,1 no Centro-Oeste, conforme os dados da Tabela 3.

A inserção prematura no mundo do trabalho obriga muitas crianças e adolescentes a conjugarem a escola com o trabalho, ou, até mesmo, a se dedicarem exclusivamente às atividades laborais, principalmente naquelas áreas onde a produção rural é predominante e a mão-de-obra infanto-juvenil mais utilizada, como o Nordeste e o Sul do Brasil. Mas não é desprezível a presença dos que não frequentam a escola ou não trabalham nem estudam, porque se dedicam aos afazeres domésticos, para que os pais ou outros membros da família possam trabalhar. Ilustrando esse fenômeno, Rizzini (2007, p.382) cita o caso de uma menina que, com apenas 8 anos, substitui a mãe nesses afazeres, limpando a casa, lavando, passando e cuidando de uma irmã de um ano. Ao ser entrevistada, declarou que (como as demais crianças) gosta mesmo é de brincar com sua boneca, "porque ela não faz xixi nem cocô quando eu dou mamadeira".

Como a luta pela sobrevivência pode começar bastante cedo, até certa idade as crianças trabalham principalmente com familiares, e sua ocupação deve ser conciliada com a escola. 25,9\% desses meninos e meninas tinham uma jornada semanal de até 14 horas e $46,0 \%$ de 15 a 39 horas de trabalho, sendo os mais novos os mais poupados. Mas como essa conciliação nem sempre é observada e tem uma duração relativamente curta, na faixa dos 14 a 17 anos uma grande parcela tinha uma jornada de adultos, trabalhando 40 horas ou mais. Era o caso de $33,7 \%$ dos que residiam no Norte, $27,4 \%$ no Nordeste, $45,5 \%$ no Sudeste, $37,5 \%$ no Sul, $43,7 \%$ no Centro Oeste e $28,1 \%$ no conjunto do país. E, embora aqueles com uma jornada igual ou superior a 49 horas por semana tivessem uma frequência relativamente minoritária, vale ressaltar que, em termos absolutos, ela correspondia a 310 mil crianças e adolescentes em uma situação indesejável para os próprios adultos. As diferenças regionais observadas na Tabela 4 que se segue estão associadas às diferenças existentes em termos da organização das atividades econômicas nos diversos espaços do território brasileiro e dos padrões de inserção do trabalho infanto-juvenil nessa organização.

Como não possuem autonomia e trabalham, principalmente, como auxiliares de membros da unidade domiciliar, quase metade das crianças e adolescentes não recebia qualquer remuneração; nos casos em que a remuneração existia, tratavase, normalmente, de ganhos irrisórios. Até os 13 anos, praticamente eles não iam além de um quarto ou de meio salário mínimo. Entre 14 e 17 anos, esse continuava sendo o valor predominante, ainda que perto de um quarto dos pequenos trabalhadores percebesse de meio a um salário mínimo e uma pequena parcela acima disso. Como seria de se esperar, há diferenças regionais significativas quanto a essa remuneração, bem mais baixa no Norte e Nordeste que em outras regiões.

Marcado pelas condições adversas do seu exercício e por uma extrema exploração, o trabalho precoce tem consequências bastante conhecidas e nefastas sobre o desenvolvimento, a educação e a saúde dos seus pequenos executores.

Crianças e adolescentes ocupados encontram, no trabalho, um significativo obstáculo ao ingresso, à permanência e ao sucesso no sistema educacional. Como vislumbram para a geração sucessiva o que não conseguiram obter e o aumen- 
Tabela 3 - População ocupada entre 5 e 17 anos, segundo a posição na ocupação (em percentuais) Brasil e Grandes Regióes - 2006

\begin{tabular}{|c|c|c|c|c|}
\hline Brasil e Grandes Regiōes & Total & 5 a 9 anos & 10 a 13 anos & 14 a 17 anos \\
\hline \multicolumn{5}{|l|}{ Brasil } \\
\hline Empregado & 51,4 & 4,8 & 23,4 & 61,1 \\
\hline Trabalhador doméstico & 12,9 & 0,6 & 11,1 & 14,4 \\
\hline Conta própria & 10,2 & 3,6 & 17,6 & 9,4 \\
\hline Trab. não-remunerado de membro da unidade domiciliar & 21,2 & 57,0 & 43,2 & 13,7 \\
\hline Outro trabalhador não-remunerado & 1,4 & 1,2 & 2,8 & 1,1 \\
\hline Trab. na produção para o próprio consumo & 3,0 & 33,0 & 1,8 & 0,3 \\
\hline \multicolumn{5}{|l|}{ Norte } \\
\hline Empregado & 31,9 & 1,5 & 15,3 & 41,2 \\
\hline Trabalhador doméstico & 15,5 & 0,0 & 8,4 & 19,8 \\
\hline Conta própria & 9,8 & 6,0 & 7,5 & 11,0 \\
\hline Trab. não-remunerado de membro da unidade domiciliar & 37,6 & 51,2 & 67,1 & 26,7 \\
\hline Outro trabalhador não-remunerado & 1,1 & 0,0 & 1,4 & 1,2 \\
\hline Trab. na produção para o próprio consumo & 4,1 & 41,3 & 0,5 & 0,1 \\
\hline \multicolumn{5}{|l|}{ Nordeste } \\
\hline Empregado & 33,4 & 4,4 & 19,0 & 43,7 \\
\hline Trabalhador doméstico & 15,0 & 0,7 & 10,1 & 19,5 \\
\hline Conta própria & 14,7 & 3,7 & 21,9 & 14,8 \\
\hline Trab. não-remunerado de membro da unidade domiciliar & 30,8 & 64,4 & 44,4 & 19,8 \\
\hline Outro trabalhador não-remunerado & 1,9 & 1,9 & 2,6 & 1,6 \\
\hline Trab. na produção para o próprio consumo & 4,2 & 24,8 & 2,0 & 0,6 \\
\hline \multicolumn{5}{|l|}{ Sudeste } \\
\hline Empregado & 65,5 & 13,8 & 30,2 & 71,4 \\
\hline Trabalhador doméstico & 10,5 & 1,4 & 9,4 & 10,9 \\
\hline Conta própria & 9,4 & 2,2 & 24,6 & 7,7 \\
\hline Trab. não-remunerado de membro da unidade domiciliar & 11,6 & 35,7 & 28,9 & 8,8 \\
\hline Outro trabalhador não-remunerado & 1,1 & 0,0 & 3,7 & 0,8 \\
\hline Trab. na produção para o próprio consumo & 1,8 & 46,9 & 3,1 & 0,3 \\
\hline \multicolumn{5}{|l|}{ Sul } \\
\hline Empregado & 61,2 & 3,0 & 30,4 & 70,9 \\
\hline Trabalhador doméstico & 10,8 & 0,0 & 16,0 & 11,1 \\
\hline Conta própria & 5,6 & 2,1 & 7,0 & 5,8 \\
\hline Trab. não-remunerado de membro da unidade domiciliar & 18,0 & 53,8 & 43,3 & 11,1 \\
\hline Outro trabalhador não-remunerado & 1,3 & 0,0 & 2,9 & 1,2 \\
\hline Trab. na produção para o próprio consumo & 3,1 & 41,1 & 0,4 & 0,0 \\
\hline \multicolumn{5}{|l|}{ Centro oeste } \\
\hline Empregado & 58,4 & 0,0 & 27,7 & 65,1 \\
\hline Trabalhador doméstico & 16,7 & 0,0 & 22,3 & 16,7 \\
\hline Conta própria & 6,4 & 3,3 & 5,6 & 6,7 \\
\hline Trab. não-remunerado de membro da unidade domiciliar & 15,5 & 50,3 & 40,7 & 10,5 \\
\hline Outro trabalhador não-remunerado & 1,1 & 3,8 & 2,5 & 0,8 \\
\hline Trab. na produção para o próprio consumo & 1,9 & 42,6 & 1,2 & 0,2 \\
\hline
\end{tabular}

to da escolaridade dos filhos, é parte da realização capacidade física como a necessidade de conciliar do seu papel de pais que os chefes das famílias em essa inserção com a frequência ao sistema elemenapreço normalmente procurem inserir os filhos no tar de ensino. Por isso, pelo menos nas áreas urbamercado de trabalho, levando em conta tanto a sua nas, a maioria absoluta dessas crianças e adoles- 
Tabela 4 - População ocupada entre 5 e 17 Anos, segundo a jornada de trabalho (em percentuais) Brasil e Grandes Regiōes - 2006

\begin{tabular}{|c|c|c|c|c|}
\hline Brasil e Grandes Regiōes & Total & 5 a 9 anos & 10 a 13 anos & 14 a 17 anos \\
\hline \multicolumn{5}{|l|}{ Brasil } \\
\hline Até 14 horas & 25,9 & 73,7 & 46,8 & 16,4 \\
\hline 15 a 39 horas & 46,0 & 25,0 & 48,0 & 46,7 \\
\hline 40 a 44 horas & 15,5 & 1,0 & 3,0 & 20,3 \\
\hline 45 a 48 horas & 6,6 & 0,0 & 0,8 & 8,8 \\
\hline 49 horas ou mais & 6,0 & 0,2 & 1,4 & 7,9 \\
\hline \multicolumn{5}{|l|}{ Norte } \\
\hline Até 14 horas & 27,0 & 64,2 & 43,9 & 16,2 \\
\hline 15 a 39 horas & 49,1 & 35,3 & 49,8 & 49,9 \\
\hline 40 a 44 horas & 12,7 & 0,6 & 3,9 & 17,7 \\
\hline 45 a 48 horas & 6,7 & 0,0 & 1,8 & 9,4 \\
\hline 49 horas ou mais & 4,5 & 0,0 & 0,6 & 6,6 \\
\hline
\end{tabular}

\section{Nordeste}

\begin{tabular}{l|r|r|r|r}
\hline Até 14 horas & 28,7 & 70,4 & 41,8 & 18,8 \\
\hline 15 a 39 horas & 51,5 & 28,6 & 53,9 & 52,8 \\
\hline 40 a 44 horas & 10,1 & 1,1 & 2,5 & 14,4 \\
\hline 45 a 48 horas & 4,2 & 0,0 & 0,2 & 6,4 \\
\hline 49 horas ou mais & 5,4 & 0,0 & 1,6 & 7,6 \\
\hline
\end{tabular}

\section{Sudeste}

\begin{tabular}{l|r|r|r|r}
\hline Até 14 horas & 20,5 & 75,6 & 51,9 & 13,7 \\
\hline 15 a 39 horas & 40,6 & 21,4 & 41,4 & 40,9 \\
\hline 40 a 44 horas & 21,9 & 3,0 & 3,7 & 25,6 \\
\hline 45 a 48 horas & 9,9 & 0,0 & 1,7 & 11,6 \\
\hline 49 horas ou mais & 7,1 & 0,0 & 1,3 & 8,3 \\
\hline
\end{tabular}

Sul 14 horas

15 a 39 horas

40 a 44 horas

45 a 48 horas

49 horas ou mais

\begin{tabular}{l|r|r|r|r} 
& 30,4 & 89,8 & 58,4 & 18,5 \\
\hline & 40,9 & 8,7 & 37,0 & 44,1 \\
\hline mais & 16,9 & 0,0 & 2,5 & 22,2 \\
\hline
\end{tabular}

Centro oeste

Até 14 hora

15 a 39 horas

œ 40 a 44 horas

क 45 a 48 horas

is 49 horas ou mais

Fonte: IBGE/PNAD, 2006. Dados tabulados para este trabalho.

centes frequenta a escola, e, se essa frequência decai nas áreas rurais, é provável que isso se deva tanto às exigências da ocupação quanto à carência de vagas e a outras características do referido sistema, uma vez que as matrículas se reduzem tanto para os ocupados como para o conjunto de menores de 18 anos que residem nessas áreas.

Pertencendo a famílias pobres e com baixo capital cultural e tendo acesso a um ensino públi- co de má qualidade, ${ }^{8}$ que não atende às suas necessidades e expectativas, os pequenos trabalha-

${ }^{8}$ Como se sabe, em maior ou menor grau, essas escolas geralmente reproduzem as condições encontradas por pesquisa realizada por Celso Fávero e Stella Rodrigues (citada por Pedreira, 2005) na região do semi-árido baiano: funcionam em instalações improvisadas, com professores pouco qualificados, utilizando metodologias tradicionais, passivas, baseadas na memorização, dando pouca importância ao desenvolvimento do pensar. Carecem de livros e materiais didáticos necessários e contextualizados, têm classes heterogêneas e seus planos e programas de aula têm muito pouca relação com o cotidiano dos alunos. 
Tabela 5 - População ocupada entre 5-17 anos, segundo o rendimento do trabalho (em salários mínimos e percentuais) Brasil e Grandes Regióes - 2006

\begin{tabular}{|c|c|c|c|c|}
\hline Brasil e Grandes Regiōes & Total & 5 a 9 anos & 10 a 13 anos & 14 a 17 anos \\
\hline \multicolumn{5}{|l|}{ Brasil } \\
\hline Até $1 / 4$ & 14,1 & 8,0 & 16,6 & 13,7 \\
\hline Mais de $1 / 4$ a $1 / 2$ & 12,7 & 0,6 & 4,6 & 16,0 \\
\hline Mais de $1 / 2$ a 1 & 18,2 & 0,4 & 2,3 & 24,3 \\
\hline Mais de 1 a 2 & 6,9 & 0,0 & 0,1 & 9,4 \\
\hline Mais de 2 a 5 & 0,3 & 0,0 & 0,0 & 0,4 \\
\hline Sem declaração & 47,9 & 91,0 & 76,4 & 36,2 \\
\hline \multicolumn{5}{|l|}{ Norte } \\
\hline Até $1 / 4$ & 9,8 & 8,2 & 8,1 & 10,7 \\
\hline Mais de $1 / 4$ a $1 / 2$ & 12,0 & 0,0 & 4,8 & 16,3 \\
\hline Mais de $1 / 2$ a 1 & 13,2 & 0,6 & 2,4 & 19,1 \\
\hline Mais de 1 a 2 & 3,5 & 0,0 & 0,6 & 5,1 \\
\hline Mais de 2 a 5 & 0,2 & 0,0 & 0,0 & 0,3 \\
\hline Sem declaração & 61,3 & 91,2 & 84,2 & 48,5 \\
\hline
\end{tabular}

Nordeste

\begin{tabular}{|c|c|c|c|c|}
\hline Até $1 / 4$ & 18,4 & 8,0 & 16,4 & 20,4 \\
\hline Mais de $1 / 4$ a $1 / 2$ & 9,8 & 0,4 & 2,2 & 14,0 \\
\hline Mais de $1 / 2$ a 1 & 8,2 & 0,2 & 0,7 & 12,3 \\
\hline Mais de 1 a 2 & 0,9 & 0,0 & 0,0 & 1,4 \\
\hline Mais de 2 a 5 & 0,1 & 0,0 & 0,0 & 0,2 \\
\hline Sem declaração & 62,6 & 91,5 & 80,7 & 51,8 \\
\hline \multicolumn{5}{|l|}{ Sudeste } \\
\hline Até $1 / 4$ & 14,4 & 11,4 & 28,9 & 11,9 \\
\hline Mais de $1 / 4$ a $1 / 2$ & 16,2 & 3,0 & 8,0 & 18,0 \\
\hline Mais de $1 / 2$ a 1 & 30,6 & 1,6 & 5,6 & 35,7 \\
\hline Mais de 1 a 2 & 12,2 & 0,0 & 0,2 & 14,6 \\
\hline Mais de 2 a 5 & 0,5 & 0,0 & 0,0 & 0,6 \\
\hline Sem declaração & 26,0 & 84,0 & 57,3 & 19,1 \\
\hline \multicolumn{5}{|l|}{ Sul } \\
\hline Até $1 / 4$ & 7,8 & 6,6 & 10,4 & 7,1 \\
\hline Mais de $1 / 4$ a $1 / 2$ & 11,0 & 0,0 & 5,5 & 13,3 \\
\hline Mais de $1 / 2$ a 1 & 19,0 & 0,0 & 3,4 & 24,8 \\
\hline Mais de 1 a 2 & 13,4 & 0,0 & 0,0 & 18,2 \\
\hline Mais de 2 a 5 & 0,4 & 0,0 & 0,0 & 0,5 \\
\hline Sem declaração & 48,4 & 93,4 & 80,8 & 36,1 \\
\hline \multicolumn{5}{|l|}{ Centro oeste } \\
\hline Até $1 / 4$ & 9,1 & 3,3 & 15,0 & 8,1 \\
\hline Mais de $1 / 4$ a $1 / 2$ & 20,0 & 0,0 & 12,4 & 22,2 \\
\hline Mais de $1 / 2$ a 1 & 30,3 & 0,0 & 2,5 & 37,0 \\
\hline Mais de 1 a 2 & 8,4 & 0,0 & 0,0 & 10,3 \\
\hline Mais de 2 a 5 & 0,6 & 0,0 & 0,0 & 0,8 \\
\hline Sem declaração & 31,7 & 96,7 & 70,1 & 21,6 \\
\hline
\end{tabular}

Fonte: IBGE/PNAD, 2006. Dados tabulados para este trabalho.

dores, muitas vezes, chegam à escola já cansados, aumentar as reprovações. Com o tempo e o seu ou não conseguem freqüentá-la regularmente em acúmulo ocorre uma defasagem escolar significatidecorrência de suas responsabilidades laborais va, que se soma ao cansaço, ao desestímulo e a um (como ocorre, por exemplo, nas fases de colheita), maior envolvimento com o mercado do trabalho e o que prejudica a aprendizagem e contribui para com a ampliação das jornadas, levando muitos a 
Tabela 6 - População entre 5 e 17 anos, segundo freqüência à escola e ocupação - Brasil e Grandes Regiōes - 2006

\begin{tabular}{|c|c|c|c|c|c|c|c|c|}
\hline \multirow{3}{*}{$\begin{array}{c}\text { Brasil e } \\
\text { Grandes } \\
\text { Regiōes }\end{array}$} & \multicolumn{8}{|c|}{ Crianças de 5 a 17 anos } \\
\hline & \multicolumn{4}{|c|}{ Total } & \multicolumn{4}{|c|}{ Ocupados } \\
\hline & Total & 5 a 9 anos & 10 a 13 anos & 14 a 17 anos & Total & 5 a 9 anos & 10 a 13 anos & 14 a 17 anos \\
\hline Brasil & $\mathbf{9 2 , 2}$ & $\mathbf{9 3 , 0}$ & $\mathbf{9 8 , 1}$ & $\mathbf{8 5 , 1}$ & $\mathbf{8 1 , 0}$ & $\mathbf{9 3 , 1}$ & $\mathbf{9 6 , 0}$ & $\mathbf{7 5 , 5}$ \\
\hline Norte & 89,0 & 87,6 & 96,8 & 82,5 & 79,5 & 88,2 & 93,9 & 72,3 \\
\hline Nordeste & 91,6 & 93,7 & 97,5 & 83,0 & 82,3 & 93,3 & 96,2 & 75,1 \\
\hline Sudeste & 93,9 & 95,3 & 98,6 & 87,5 & 78,9 & 98,4 & 95,4 & 75,4 \\
\hline Sul & 91,2 & 90,4 & 98,6 & 84,1 & 82,4 & 93,9 & 97,1 & 77,3 \\
\hline Centro Oeste & 91,6 & 90,4 & 98,5 & 85,9 & 81,2 & 85,1 & 98,4 & 77,6 \\
\hline Urbano & $\mathbf{9 3 , 2}$ & $\mathbf{9 4 , 3}$ & $\mathbf{9 8 , 4}$ & $\mathbf{8 6}, 7$ & $\mathbf{8 0 , 1}$ & $\mathbf{9 3}, 4$ & $\mathbf{9 5 , 8}$ & 76,6 \\
\hline Norte & 91,0 & 90,1 & 97,3 & 85,5 & 79,6 & 84,7 & 93,4 & 75,9 \\
\hline Nordeste & 92,8 & 95,2 & 97,6 & 84,9 & 79,8 & 93,5 & 94,7 & 74,2 \\
\hline Sudeste & 94,5 & 95,9 & 98,8 & 88,6 & 80,4 & 96,9 & 96,5 & 78,0 \\
\hline Sul & 91,8 & 91,5 & 98,9 & 84,7 & 79,6 & 96,2 & 98,0 & 76,0 \\
\hline Centro Oeste & 92,4 & 91,8 & 98,6 & 86,6 & 81,4 & 82,4 & 99,3 & 78,9 \\
\hline Rural & $\mathbf{8 7 , 9}$ & 87,8 & $\mathbf{9 7 , 1}$ & 78,4 & 82,2 & $\mathbf{9 2 , 9}$ & 96,1 & 73,4 \\
\hline Norte & 83,6 & 80,5 & 95,5 & 74,0 & 79,4 & 89,8 & 94,1 & 68,3 \\
\hline Nordeste & 89,1 & 90,4 & 97,3 & 79,1 & 84,3 & 93,2 & 97,0 & 76,1 \\
\hline Sudeste & 87,7 & 89,3 & 96,8 & 76,8 & 72,3 & 100,0 & 93,4 & 62,2 \\
\hline Sul & 88,2 & 85,2 & 97,7 & 81,4 & 86,4 & 92,4 & 96,6 & 80,0 \\
\hline Centro Oeste & 87,3 & 82,7 & 98,1 & 80,6 & 80,7 & 85,8 & 97,4 & 73,0 \\
\hline
\end{tabular}

Fonte: IBGE/PNAD, 2006. Dados tabulados para este trabalho.

abandonarem o sistema educacional precocemente, com baixos níveis de escolaridade.

Contribuindo para antecipar o fim da infância e da adolescência e para uma inserção no mundo do trabalho como adultos, esses fenômenos ficam claros através das Tabelas 6 e 7. A primeira delas evidencia como a frequência à escola de crianças e adolescentes ocupados é sistematicamente inferior à registrada para a população entre 5 e 17 anos, nas áreas urbanas, nas áreas rurais e no conjunto do país. Além disso, a partir dos 14 anos, essa frequência cai significativamente, passando de $95,8 \%$ entre os ocupados na faixa de 10 a13 anos para 76,6\% entre a de 14 a 17 anos nas áreas urbanas, de 96,1\% para 73,4\% nas áreas rurais e de $96,0 \%$ para $75,5 \%$ no conjunto do país. Essa queda é ainda mais acentuada nas regiões Norte e Sudeste, onde a proporção de ocupados que ainda frequentavam a escola entre 14 e 17 anos não ia além de 68,3\% e 62,2\%.
Já a Tabela 7 mostra como a atividade precoce está associada ao atraso escolar, especificando as diferenças entre as diversas regióes. Seus dados deixam patente como, entre as meninas e meninos ocupados, a freqüência daqueles sem atraso escolar é sistematicamente inferior ao constatado entre o conjunto de alunos da mesma faixa etária, e, também, como esse atraso se acumula com o tempo, contribuindo para a evasão precoce do sistema educacional. Embora os dados falem por si mesmos, vale ressaltar como, nas regiões Norte e Nordeste, esse fenômeno assume uma especial gravidade, uma vez que, na faixa de 14 a 17 anos, mais da metade dos ocupados apresenta um atraso escolar igual ou superior a quatro anos, e um quarto ou até mais deles um atraso igual ou superior a seis anos. ${ }^{9}$

${ }^{9}$ É claro que isso decorre de uma interação de fatores, pois o atraso também está estreitamente associado à pobreza dessas crianças e adolescentes e à maior precariedade do sistema de ensino público. Mas o peso do trabalho precoce tem sido destacado por diversos estudos e também fica patente quando se observa que esse atraso (especialmente quando igual ou superior a 4 e 5 anos ou a 6 anos 
Tabela 7 - População entre 5 e 17 anos, segundo anos de atraso escolar (em percentuais). Brasil e Grandes Regiōes - 2006

\begin{tabular}{|c|c|c|c|c|c|c|c|c|}
\hline \multirow{3}{*}{$\begin{array}{c}\text { Brasil e Grandes } \\
\text { Regiôes }\end{array}$} & \multicolumn{8}{|c|}{ População entre 5-17 Anos } \\
\hline & \multicolumn{2}{|c|}{$5-17$} & \multicolumn{2}{|c|}{$5-9$} & \multicolumn{2}{|c|}{$10-13$} & \multicolumn{2}{|c|}{ 14-17 } \\
\hline & Total & Ocupados & Total & Ocupados & Total & Ocupados & Total & Ocupados \\
\hline \multicolumn{9}{|l|}{ Brasil } \\
\hline Sem atraso escolar & 23,6 & 8,0 & 48,6 & 29,7 & 11,1 & 9,8 & 6,3 & 6,0 \\
\hline 1 ano de atraso & 38,1 & 25,9 & 39,3 & 37,2 & 44,2 & 29,6 & 30,4 & 24,1 \\
\hline 2 ou 3 anos & 26,8 & 34,5 & 12,1 & 33,1 & 35,3 & 39,9 & 35,6 & 32,9 \\
\hline 4 ou 5 anos & 7,9 & 19,1 & 0,0 & 0,0 & 8,1 & 18,2 & 17,1 & 20,7 \\
\hline 6 anos ou mais & 3,7 & 12,5 & 0,0 & 0,0 & 1,2 & 2,6 & 10,6 & 16,4 \\
\hline \multicolumn{9}{|l|}{ Norte } \\
\hline Sem atraso escolar & 23,0 & 5,3 & 47,9 & 23,8 & 8,8 & 7,3 & 5,1 & 2,8 \\
\hline 1 ano de atraso & 29,1 & 14,3 & 34,7 & 33,5 & 31,8 & 16,5 & 18,7 & 11,6 \\
\hline 2 ou 3 anos & 30,6 & 37,0 & 17,4 & 42,7 & 42,1 & 45,2 & 35,9 & 32,8 \\
\hline 4 ou 5 anos & 11,5 & 25,1 & 0,0 & 0,0 & 14,6 & 23,8 & 23,6 & 27,8 \\
\hline 6 anos ou mais & 5,7 & 18,4 & 0,0 & 0,0 & 2,6 & 7,2 & 16,7 & 25,0 \\
\hline \multicolumn{9}{|l|}{ Nordeste } \\
\hline Sem atraso escolar & 22,9 & 5,7 & 49,2 & 26,0 & 10,1 & 6,8 & 4,2 & 3,2 \\
\hline 1 ano de atraso & 28,7 & 15,5 & 34,8 & 36,6 & 31,8 & 21,0 & 18,3 & 11,1 \\
\hline 2 ou 3 anos & 30,3 & 34,2 & 16,0 & 37,4 & 42,5 & 44,0 & 35,1 & 29,6 \\
\hline 4 ou 5 anos & 11,9 & 25,5 & 0,0 & 0,0 & 13,8 & 25,3 & 24,3 & 28,2 \\
\hline 6 anos ou mais & 6,2 & 19,0 & 0,0 & 0,0 & 1,9 & 2,9 & 18,1 & 27,9 \\
\hline \multicolumn{9}{|l|}{ Sudeste } \\
\hline Sem atraso escolar & 21,5 & 7,0 & 45,8 & 20,2 & 9,0 & 11,0 & 5,5 & 6,0 \\
\hline 1 ano de atraso & 46,3 & 37,0 & 44,4 & 41,0 & 54,6 & 42,0 & 40,4 & 36,0 \\
\hline 2 ou 3 anos & 25,3 & 35,0 & 9,8 & 38,8 & 31,9 & 36,3 & 36,9 & 34,7 \\
\hline 4 ou 5 anos & 4,9 & 13,9 & 0,0 & 0,0 & 4,0 & 10,1 & 11,5 & 14,9 \\
\hline 6 anos ou mais & 2,0 & 7,2 & 0,0 & 0,0 & 0,7 & 0,8 & 5,7 & 8,5 \\
\hline \multicolumn{9}{|l|}{ Sul } \\
\hline Sem atraso escolar & 28,7 & 15,5 & 52,1 & 49,6 & 17,2 & 16,6 & 12,8 & 13,0 \\
\hline 1 ano de atraso & 43,2 & 38,0 & 40,6 & 40,7 & 52,7 & 50,9 & 36,2 & 34,0 \\
\hline 2 ou 3 anos & 21,0 & 31,5 & 7,4 & 9,7 & 25,2 & 28,8 & 33,0 & 33,6 \\
\hline 4 ou 5 anos & 5,2 & 10,7 & 0,0 & 0,0 & 4,2 & 3,7 & 12,6 & 13,4 \\
\hline 6 anos ou mais & 1,9 & 4,3 & 0,0 & 0,0 & 0,7 & 0,0 & 5,5 & 5,9 \\
\hline \multicolumn{9}{|l|}{ Centro oeste } \\
\hline Sem atraso escolar & 28,4 & 11,5 & 55,1 & 46,6 & 16,9 & 21,2 & 8,7 & 8,3 \\
\hline 1 ano de atraso & 36,6 & 28,2 & 35,6 & 32,0 & 42,6 & 36,0 & 31,4 & 26,4 \\
\hline 2 ou 3 anos & 25,6 & 37,2 & 9,2 & 21,3 & 34,4 & 33,5 & 35,9 & 38,4 \\
\hline 4 ou 5 anos & 6,8 & 15,6 & 0,0 & 0,0 & 5,4 & 8,1 & 16,3 & 17,6 \\
\hline 6 anos ou mais & 2,6 & 7,6 & 0,0 & 0,0 & 0,8 & 1,2 & 7,6 & 9,1 \\
\hline
\end{tabular}

Não menos preocupantes são os riscos e os danos da ocupação precoce à saúde dos seus executores, fisicamente mais vulneráveis e mais susceptíveis a doenças e lesões relacionadas ao trabalho que os adultos. Aqueles em atividade na agri-

e mais) é bem mais acentuado no grupo dos ocupados nas mesmas regiões. cultura, ${ }^{10}$ por exemplo, estão expostos a radiação solar, calor, umidade, chuva e picadas de insetos e animais peçonhentos; ao levantamento e transpor-

${ }^{10}$ Dados da PNAD de 2006, divulgados pela Folha de São Paulo de 12 jun. 2008, p.B9, mostram que 51,5\% das crianças e adolescentes que se feriram ou adoeceram nos 365 dias anteriores à pesquisa atuavam na agricultura, onde foram vítimas do contacto com agrotóxicos e do uso de facas, enxadas e foices não adaptadas para uso infantil. 
te manual de peso excessivo, acidentes com instrumentos perfuro-corte-contusos, doenças respiratórias e contaminação com agrotóxicos. Tais riscos podem levar a queimaduras na pele, envelhecimento precoce, desidratação, câncer de pele, fadiga física, dores musculares nos membros e na coluna vertebral, comprometimento do desenvolvimento físico-motor, intoxicações, ferimentos e contusões, acidentes, traumatismos e doenças respiratórias. Os que trabalham na coleta de material reciclável correm o risco de acidentes com objetos e resíduos perfuro-cortantes, muitas vezes contaminados, picadas de insetos e animais peçonhentos, contaminação por produtos químicos descartados, atropelamentos, acidentes de trânsito e exposição à violência, podendo sofrer ferimentos e doenças infecto-contagiosas, reações na pele generalizadas, traumatismos, ferimentos e comprometimento do desenvolvimento afetivo.

Em cerâmicas e olarias, meninas e (principalmente) meninos são vulneráveis a levantamento e transporte manual de peso excessivo, exposição à poeira, calor e umidade, acidentes com máquinas e quedas, tendo como possíveis consequências fadiga, dores musculares nos membros e coluna vertebral, doenças respiratórias, fraturas, mutilações, choques elétricos e a própria morte. Em marcenarias, estão expostos a poeira, ruídos e vibrações, substâncias químicas e posturas inadequadas, que podem causar perda de audição, lesões articulares, fadiga, depressão medular, lesões dermatológicas, alergias e anemias. Na construção civil, há riscos de levantamento e transporte manual de material com peso excessivo, exposição à radiação solar, exposição a poeira e a níveis elevados de pressão sonora, tendo como consequências a fadiga física, dores musculares, nos membros e coluna vertebral, queimaduras de pele, envelhecimento precoce e perda auditiva, entre outras.

Crianças e adolescentes ocupados no comércio ambulante, uma das suas principais atividades nas áreas urbanas, estão expostas ao levantamento e transporte manual de peso excessivo, manutenção de posturas inadequadas, movimentos repetitivos, exposição à radiação solar, calor, umidade e chuva, acidentes de trânsito, atropelamentos, exposição à violência, drogas e assédio sexual, que ocasionam fadiga física, dores musculares, nos membros e coluna vertebral, lesões e deformidades osteomoleculares, queimaduras na pele, envelhecimento precoce, desidratação, doenças respiratórias, traumatismos, ferimentos, dependência química, atividade sexual precoce, doenças sexualmente transmissíveis e gravidez indesejada. No serviço doméstico, há riscos de fadigas, queimaduras, maus tratos e atraso do desenvolvimento físico, emocional e psíquico; na fumicultura, uma exposição mais acentuada à nicotina e aos agrotóxicos, com riscos de intoxicação aguda e crônica. A fabricação de fogos de artifício, muitas vezes realizada de forma clandestina e inadequada, tem levado a doenças respiratórias, lesões dermatológicas, queimaduras eà própria morte em explosões. (Ministério do Trabalho e Emprego, 2005).

Apesar desses danos e riscos e das disposições legais, persiste a demanda por essa força de trabalho específica, inclusive por parte de setores e empresas que não podem ser exatamente classificados como tradicionais, até porque certas tarefas são mais bem realizadas pelas mãos delicadas das crianças. Ao contrário dos adultos, elas sobem nas árvores com agilidade e conseguem colher laranjas sem quebrar os galhos. Empregadores da agroindústria elogiam sua paciência e cuidado no perigoso e insalubre trabalho de espalhar agrotóxicos nas plantações. Por isso, conforme menciona Rizzini (2007), em Minas Gerais, por exemplo, fica a cargo das "meninas formicida" a tarefa de colocar veneno nos formigueiros das fazendas de reflorestamento com eucalipto, e, no norte do estado do Rio de Janeiro, os "florzinha" polinizam as plantações de maracujá junto com suas famílias, recebendo remunerações irrisórias. Em São Paulo, crianças e adolescentes trabalham clandestinamente em fábricas de plástico e vidro, ganhando metade do piso salarial, expostos a uma temperatura dos fornos de 1500 graus e a um ruído que chega a 195 decibéis. No Rio Grande do Sul, a mão-de-obra infanto-juvenil é intensamente 
utilizada na lavoura do fumo, a cultura que mais utiliza agrotóxicos. E, ainda que após a implementação do PETI seu número tenha experimentado uma grande redução, meninos e meninas ainda continuam expostos a danos físicos e até mutilações na produção de sisal no sertão da Bahia, ou a riscos de explosões na produção clandestina de fogos, como ocorreu em Santo Antonio de Jesus, no mesmo estado, com a morte de mais de 100 pessoas, incluindo muitas crianças. ${ }^{11}$

Mas os efeitos da ocupação precoce podem ser mais bem ilustrados pelo depoimento de um menino de 14 anos, ocupado no corte de cana no interior do estado do Rio de Janeiro, que ganha de $\mathrm{R} \$ 36,00$ a $\mathrm{R} \$ 40,00$ por mês, entregues à família para ajudar no pagamento de pão e da luz. Entrevistado em pesquisa de Neves e perguntado se gostava do seu trabalho, ele declarou que:

Eu, não. Ah, é cansativo. A gente sente muita dor nos braços, no corpo todo. Gente que trabalha na roça sente o corpo todo. Quando deita para dormir, é muita dor, sabe? E de manhã, pra levantar de novo...! Porque parece que esfria, não é, aí fica doendo. Dói tudo! Tanto dói aqui, como dói as costas. Arde aqui. Dá uma ardência aqui por causa de ficar puxando o facão o dia todo. (Neves, 2004, p.209).

\section{ALGUMAS CONSIDERAÇÕES FINAIS}

Ao longo das páginas anteriores deste texto, foi assinalado como a exploração da mão-de-obra infanto-juvenil tem uma longa trajetória na sociedade brasileira, com a sua ocupação sendo considerada, até alguns anos atrás, como a sina das crianças pobres e um instrumento pedagógico capaz de transformá-las em indivíduos úteis à sociedade e em futuros bons cidadãos; que, a partir da década de 1980, houve um amplo questionamento dessas concepções e das políticas assistencialistas e correcionais repressivas por elas orientadas, quando movimentos em defesa da infância e da adoles-

${ }^{11}$ Sobre as perversas condições de exercício do trabalho precoce, ver, entre outros, Martins (1993), Huzak e Azevedo (1994), Neves (1999), Azevedo, Menezes e Fernandes (2000), Liebel (2003), Frigotto (2003), Pedreira (2006), Dourado, Dabat; Araújo (2007), Rizzini (2007), Del Priori (2007). cência definiram um conjunto de direitos que deveriam ser assegurados a todos nessa etapa de vida, sem distinção de classe social, institucionalizando esses direitos na Constituição de 1988 e no Estatuto da Criança e do Adolescente e lutando pela sua efetivação.

Também foi visto como, na esteira desses processos, começaram a ser implementados diversas iniciativas e programas de combate ao trabalho precoce, privilegiando as suas consideradas "piores formas", e como isso resultou em uma redução desse problema que não pode ser menosprezada. Em poucos anos, porém, os impactos dessas medidas chegaram a um limite, a tendência de redução desse trabalho tornou-se mais lenta e, com isso, milhares de crianças e adolescentes brasileiros continuam tendo que colaborar com a família ou assegurar a própria sobrevivência trabalhando prematuramente e em condições bastante adversas, com prejuízos para o seu desenvolvimento e o seu futuro.

Apesar da proibição legal desse trabalho, da sua relativa deslegitimação no plano simbólico e dos movimentos e iniciativas que vêm sendo desenvolvidos para combatê-lo, nas condições do desenvolvimento brasileiro, ele parece ser um problema de muito difícil erradicação. Suas raízes estão na desigualdade social, na concentração da propriedade da terra e da renda e na pobreza de uma ampla parcela da população brasileira, uma vez que a ocupação precoce de crianças e adolescentes só pode ser compreendida a partir do padrão de organização de certos setores da economia e das condições de inserção produtiva de uma grande parcela dos trabalhadores. Tais condições impossibilitam aos pais o pleno cumprimento das suas responsabilidades pela subsistência da família, obrigando-os a se valerem do esforço conjunto dos seus componentes (sem excluir os mais jovens), da contribuição da aposentadoria dos membros mais idosos que conseguem ter acesso a esse benefício, do recurso a entidades e programas assistenciais e de outras estratégias para assegurar a sua manutenção.

É o caso dos ocupados na agroindústria canavieira, por exemplo, onde o pagamento de 
salários por produção intensifica a exploração da mão-de-obra, barateando o preço da força de trabalho e reduzindo o valor dos salários reais, e, com isso, levando a ocupação dos filhos a se tornar parte das condições de existência desses trabalhadores, a ponto de obrigá-los a se responsabilizar pela inserção produtiva dessas crianças e adolescentes e até a escondê-la da fiscalização dos órgãos públicos. Ou dos fumicultores do sul do país, cultura que demanda bastante mão-de-obra em todas as operações. Explorando pequenas propriedades e subordinados à indústria do fumo (que fornece um pacote tecnológico e financiamento e compra a produção dos seus assistidos, terminando, com isso, por controlar praticamente o seu preço), assim como outros pequenos produtores rurais e urbanos, eles dependem de toda a família para assegurar essa produção, envolvendo os filhos nela desde muito cedo. ${ }^{12}$

Não é por acaso que $49,2 \%$ da população ocupada entre 5 e 17 anos pertencia a famílias em condições de pobreza $(25,3 \%)$, ou de indigência $(23,9 \%)$, e que quanto menor era a renda per capita das famílias, mais precocemente se verificava essa inserção laboral. Na faixa de 5 a 9 anos, por exemplo, $60,2 \%$ dos pequenos trabalhadores viviam em famílias pobres $(17,2 \%)$ ou indigentes (43,0\%), e essa freqüência era especialmente acentuada na região Nordeste $(24,5 \%$ e $64,4 \%)$ e na área rural $\left(33,4 \%\right.$ e $48,3 \%$, respectivamente). ${ }^{13}$

Mas o trabalho precoce não se deve apenas a razões de ordem econômica, estando igualmente

${ }^{12}$ Como seria de esperar, de acordo com a situação dos pais, as condições das crianças ocupadas em propriedades da família sofrem variações. Algumas são mais poupadas, reduzem as atividades quando começam as aulas (mesmo que isso implique uma redução da produção) e têm um padrão de vida satisfatório: alimentam-se bem, vestem-se adequadamente e possuem alguma forma de lazer. Mas outras pegam um trabalho mais pesado e cansativo, são mais expostas a riscos (como o contato com agrotóxicos) e podem até deixar a escola por exigências da ocupação. Ver, a esse respeito, Huzack e Azevedo (1994), Neves (1999 e 2004) e Rizzini (2007).

${ }^{13}$ Isso deixa clara a necessidade de políticas especialmente direcionadas ao combate ao trabalho infantil, pois, embora algumas dessas famílias possam estar sendo atendidas pelo programa Bolsa Família, que exige a frequência das crianças à escola, esse programa não assegura seu afastamento das atividades laborais, conforme dados do suplemento da PNAD 2006 sobre os beneficiários dos programas de transferência de renda do governo federal. associado à carência de uma rede de instituições e políticas sociais que apóiem efetivamente as famílias pobres na reprodução física e social dos seus filhos e a um complexo sistema de valores e representações. Muitas crianças começam a acompanhar os pais no trabalho desde cedo também pela carência de creches e outras de instituições onde possam ser deixadas com proteção e segurança, e os programas de assistência às famílias pobres, implantados mais recentemente, têm uma cobertura insuficiente e impactos restritos sobre os seus

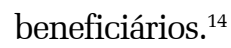

Por outro lado, também é preciso levar em conta que a experiência histórica, a cultura e o autoritarismo social brasileiro condensaram uma malha de múltiplos preconceitos, estigmas e discriminações que atingem o trabalhador desqualificado, de ocupação incerta e precária, assim como os desempregados, através de uma associação determinista e reducionista entre pobreza e delinqüência, considerando aqueles por ela afetados como agentes da desordem, da ameaça e da violência, e reclamando sobre eles a ação repressiva e punitiva do Estado. Tentando neutralizar esses estigmas, os trabalhadores em apreço procuram provar todo o tempo que conseguiram se salvar da poluição moral da pobreza, apesar da ocupação precária ou do desemprego, dos salários insuficientes, de moradias inadequadas e de más condições de vida em geral. Nessas circunstâncias, o valor do trabalho ultrapassa a lógica do cálculo econômico e se articula também com o mundo da ordem e a moral do provedor, chefe de família, na

${ }^{14}$ Como se sabe, na década de 1990 , foram criados diversos programas de transferência de renda, orientados para os segmentos considerados como mais pobres e mais vulneráveis da população brasileira, com uma cobertura e um valor bastante restritos. Em 2003, esses programas foram unificados através do Bolsa Família, que passou a experimentar uma grande expansão, beneficiando, atualmente, cerca de 11,2 milhões de famílias pobres no Brasil. Contudo, mesmo os entusiastas do programa, como Weissheimer (2006), reconhecem que essa cobertura ainda é insuficiente e que seus impactos são limitados. Efetuando transferências de valor reduzido com algumas condicionalidades (como a frequência da família aos serviços de saúde e dos filhos à escola), o Bolsa Família tem aliviado a pobreza dos seus assistidos, viabilizando uma melhoria da alimentação, a compra de material escolar ou o pagamento de pequenas despesas básicas, como gás de cozinha e energia elétrica, mas sem mudanças mais efetivas e duradouras nas suas condições. 
medida em que

a honra, entre os pobres, não estando associada à posição social, vincula-se à virtude moral, como afirmação de si em face do olhar dos outros, sendo o trabalho um dos instrumentos fundamentais para afirmação pessoal e social (Sarti, 1996, p. 68).

A partir desses valores e representações, as famílias procuram zelar pela integridade moral dos filhos ensinando-os a respeitar os outros, a não roubar, a valorizar o trabalho e a vida familiar, preparando-os desde cedo para ocupar o seu lugar em uma sociedade bastante estratificada, onde lhes são reservadas as funções mais subalternas (Fausto; Cervini, 1991; Zaluar, 1994). Mas não é fácil transmitir tais disposições, notadamente quando pais e mães se afastam frequentemente de casa para trabalhar, as redes tradicionais de controle e socialização das crianças se desmantelam e a carência ou falência dos serviços públicos não provê a sua substituição. Além disso, a partir da observação de vida dos pais e da sua própria experiência, os adolescentes podem questionar esse projeto de vida estruturado em torno da família e do trabalho, na medida em que esse último lhes aparece como uma forma de servidão. Afinal, os postos ao seu alcance se caracterizam por serem duros, desinteressantes, mal pagos, sujeitos a longas jornadas, humilhações e autoritarismo dos patrões.

Por isso, as famílias temem a sedução das ruas, do dinheiro fácil, mas perigoso, e do envolvimento com a criminalidade, que tem levado à prisão e à morte milhares de jovens no Brasil,${ }^{15}$ mas que, muitas vezes, lhes aparecem como a única via para uma vida melhor, em uma fase em que eles testam a construção da sua autonomia frente aos pais. Preocupadas em esconjurar esses riscos, as famílias tendem a encarar a ocupação precoce como uma forma de organizar o tempo dos filhos e colocá-los no "bom caminho", mantendoos longe das ruas, das más companhias, da droga e da delinqüência e desenvolvendo a sua discipli-

${ }^{15}$ Dados do Ministério da Justiça, incluídos na versão final do Programa Nacional de Segurança Pública com Cidadania (Pronasci), revelam que, a cada hora, 7 jovens entre 18 e 29 anos ingressam no sistema prisional brasileiro. São 68,4 mil a cada ano, 187 por dia. (Folha de São Paulo, 09 jul. 2007). na, responsabilidade e ética do trabalho. Expressando esses valores e a divisão do trabalho, que organiza a interdependência entre os membros das famílias pobres, onde todos, desde cedo, devem colaborar para a subsistência do grupo doméstico, a ocupação precoce acaba sendo considerada como algo virtuoso, conforme declarações obtidas junto aos referidos trabalhadores sobre essa questão:

O trabalho é uma distração para as crianças. Se não estiverem trabalhando, vão inventar moda, fazer o que não presta. A criança deve trabalhar cedo. (Rizzini, 2007, p.390).

(O trabalho) tira os meninos da rua, tá aprendendo alguma coisa a mais e ainda ganha dinheiro. (Carvalho, 1995, p.132).

(Trabalhar) acho que está aprendendo, livra de estar na rua, brincando $\mathrm{O}$ trabalho é muito bom. (1995, p.132).

Socializadas com esses valores, as crianças tendem a aceitar a inevitabilidade do seu trabalho como parte do compromisso de solidariedade familiar e até a exaltar as suas virtudes, conforme têm constatado alguns investigadores. Interagindo com crianças ocupadas em uma grande feira livre de Salvador, por exemplo, Barros (2008, p.91) ouviu deles que embora preferissem apenas brincar e estudar,

... é bom trabalhar, porque a mãe dá comida em casa, compra pão pra tomar café.

... trabalhar é bom porque a pessoa tá precisando aí trabalha, é melhor que roubar, porque se a gente crescer vai ter que ser alguém na vida, né? ... trabalhar é melhor que roubar, do que ficar na malandragem, e trabalhar não, a gente arranja uma coisa melhor na vida.

Para os adolescentes, além de ser parte de suas obrigações como filho, o trabalho também é visto como afirmação de sua individualidade, abrindo a possibilidade de conquistar um espaço de liberdade e ter acesso a padrões de consumo e comportamentos que definem a própria identidade de jovem na nossa sociedade, como tênis, roupa "de marca” e som. Além disso, enquanto completar a escolaridade lhes parece algo distante e mais difícil (em decorrência da defasagem idade-série e do atraso acumulado), a inserção ocupacional consti- 
tui uma perspectiva mais concreta e imediata.

Por todas essas razões, pode-se concluir que o trabalho precoce e em condições adversas não poderá ser erradicado enquanto permanecerem intocadas as suas maiores determinações, como a concentração da propriedade da terra e a subordinação econômica, que afetam os pequenos produtores, a carência de políticas sociais que possam apoiar melhor a reprodução social dos trabalhadores e, principalmente, as condições de mercado de trabalho que permitem uma perversa constituição das relações de trabalho e uma extrema exploração da mãode-obra, tanto dos adultos como das crianças.

(Recebido para publicação em agosto de 2008) (Aceito em novembro de 2008)

\section{REFERÊNCIAS}

ALVIM, Maria Rosilene. O trabalho infanto-juvenil em discussão. In: MARTINS, Heloisa da S.; RAMALHO, José Ricardo. Terceirização: diversidade e negociação no mundo do trabalho. São Paulo: HUCITEC CEDI/NETS, 1994. p.123-136.

; VALLADARES, Lícia do Prado. Infância e sociedade no Brasil, uma análise da literatura. BIB, 3. São Paulo/ Rio de Janeiro: ANPOCS/Vértice, 1988.

ÀRIES, Philippe. História social da criança e da família. 2.ed. Rio de Janeiro: Zahar, 1978. 279 p.

AZEVÊDO, José Sérgio G. de; MENEZES, Wilson F.; FERNANDES, Cláudia M. Fora do lugar. Crianças e ado$205 \mathrm{p}$.

BARROS, Eliete da Silva. Criança na Feira de São Joaquim: trabalho e exploração. 2008. 103 f. Dissertação (Mestrado) - Programa de Pós-Graduação em Ciências Sociais da Faculdade de Filosofia e Ciências Humanas da - Universidade Federal da Bahia. Salvador, 2008.

เి CARVALHO, Inaiá M. M. de. Algumas liçoes do Programa de Erradicação do Trabalho Infantil. São Paulo em Perspectiva, São Paulo, Fundação SEADE, v. 18, n. 4, p. 50$\dot{2} \quad 61$, out./dez., 2004. escentes e cidadania. Revista Brasileira de Ciências Sociais. São Paulo, ANPOCS, v.29, p.127-142, 1995.

MAIA, Sylvia dos R. (Org.) Programa de Errāadicação do Trabalho Infantil. PETI. Trajetória e Beneficiários no Estado da Bahia. Salvador: SETRAS/ CRH, 2003. 395 p.

DEL PRIORI, Mary (Org.) História das crianças no Brasil. São Paulo: Contexto, 2007. 444 p.

DOURADO, Ana; DABAT, Christine; ARAÚJO, José. Crianças e adolescentes nos canaviais de Pernambuco. In: DEL PRIORE, Mary (Org.). História das crianças no Brasil. São Paulo: Contexto, 2007. p.408-436.
FAUSTO, Ayrton; CERVINI, Rubem. (Org.) O trabalho e a rua. Crianças e adolescentes no Brasil urbano dos anos 80. São Paulo: Cortez, 1991.

FOLHA DE SÃO PAULO, 29 mar. 2008. Especial A6.

26 jul. 2007, p.B6.

09 jul. 2007, p.B3.

GOES, José Roberto; FLORENTINO, Nando. Crianças escravas, crianças dos escravos. In: DEL PRIORE, Mary (Org.) História das crianças no Brasil. São Paulo: Contexto, 2007 p. 177-191.

GRUNSPUN, Haim. O trabalho das crianças e dos adolescentes. São Paulo: LTr, 2000. 160 p.

HUZAK, Iolanda; AZEVÊDO, Jô. Crianças de fibra. Rio de Janeiro: Paz e Terra, 1994. 141 p.

LIEBEL, Manfred. Infância y trabajo. Lima: IFEJANT, 2003. 344 p.

MARTINS, José de Souza. (Org.) Massacre dos inocentes. A criança sem infância no Brasil. São Paulo: HUCITEC, 1993.

MINISTÉRIO DO TRABALHO E EMPREGO. Mapa de indicativos do trabalho de criança e do adolescente. 3.ed. Brasília: TEM/SIT, 2005. 309 p.

NEVES, Delma Pessanha. A perversão do trabalho infantil. Lógicas sociais e alternativas de prevenção. Niterói: Intertexto, 1999. $241 \mathrm{p}$.

A pobreza como legado. O trabalho infantil no meio rural da sociedade brasileira. In: CONGRESSO ALAS/ IFEJANT, 24, Lima, 2004 - Infância y adolescência em América Latina, t.2. p.189-216.

PEDREIRA, Lucia Álvares. PETI: de(sen)volvendo a infância perdida. 2006. 155 f. Dissertação (Mestrado) - Programa de Pós-Graduação em Educação e Contemporaneidade da Universidade Estadual da Bahia. Salvador, 2006.

RIZZINI, Irma. Pequenos trabalhadores do Brasil. In: DEL PRIORI, Mary (Org.). História das crianças no Brasil. São Paulo: Contexto, 2007. p.376-406.

SARTI, Cyntia A. Família como espelho. Um estudo sobre a moral dos pobres. São Paulo: Autores Associados, 1996. $128 \mathrm{p}$.

SOUZA, J. F. de; SOUZA, A. L. F. Crianças e adolescentes Futuro da Região Sisaleira da Bahia? Feira de Santana: NUPEP/MOC, 2003. 235 p.

WEISSHEIMER, Marco Aurélio. Bolsa Família: avanços, limites e possibilidades de um programa que está transformando a vida de milhões de famílias no Brasil. São Paulo: Ed. Perseu Abramo, 2006. 160 p.

ZALUAR, Alba. A máquina e a revolta. As organizações populares e o significado de pobreza. São Paulo: Brasiliense, 1994. 


\section{THE CHILD LABOR IN BRASIL CONTEMPORÂNEO}

\section{Inaiá Maria Moreira de Carvalho}

This paper analyzes the current panorama of the child labor in the Brazilian society, approaching its origins, recent trajectory, effects on the children and adolescents and policies developed to combat it. Based on special tabulations of PNAD 2006, it shows the dimension of the phenomenon and how precocious activity differs according to age, sex, place of residence, rural and urban, and the geographical regions, marking their conditions of activity and the perverse impacts on the small workers education and health. Considering as much the economical determinant to child labor as the values and symbolic representations that are in the base of its reproduction, the text concludes highlighting as, in the conditions of the Brazilian development, that it is a phenomenon of difficult eradication.

KEYwORDS: child labor, children and adolescents, social inequality, Brazil.

\section{LE TRAVAIL DES ENFANTS AU SEIN DU BRESIL CONTEMPORAIN}

\author{
Inaiá Maria Moreira de Carvalho
}

Cette étude se propose d'analyser le panorama actuel du travail des enfants dans la société brésilienne, son origine, sa trajectoire récente, ses effets sur les enfants et les adolescents ainsi que les politiques mises en œuvre pour le combattre. Basée sur des analyses de données spécifiques de la PNAD 2006, elle permet de montrer la dimension du phénomène et combien l'activité précoce change en fonction de l'âge, du sexe, du lieu de résidence en zone rurale ou urbaine et des grandes régions. On y met en évidence les conditions de travail et leurs impacts pervers sur la scolarité et la santé des petits travailleurs. En prenant en considération autant les déterminants économiques que les valeurs et les représentations symboliques qui sont à la base de sa reproduction, pour conclure, cette analyse démontre combien il est difficile d'éliminer ce phénomène dans les conditions du développement brésilien.

Mots-CLÉs: travail des enfants, enfants et adolescents, inégalités sociales, Brésil.

Inaiá Maria Moreira de Carvalho - Doutora em Sociologia. Professora do Mestrado em Políticas Sociais e Cidadania da Universidade Católica de Salvador e do Programa de Pós-Graduação em Ciências Sociais da Universidade Federal da Bahia. Pesquisadora do Centro de Recursos Humanos da Universidade Federal da Bahia. Bolsista do CNPq-IB. Participa de várias sociedades científicas, tendo integrado diretorias da ANPOCS e da SBPC, e comitês editoriais de várias revistas científicas. Foi coordenadora da pesquisa da Pró-Reitoria de Pesquisa e Pós-graduação da UFBA (1995-1998). Tem vários livros publicados além de artigos em periódicos nacionais e estrangeiros. Suas pesquisas têm versado atualmente sobre temas como reestruturação produtiva, transformações urbanas e políticas sociais. 